\title{
Iran dybt splittet
}

\section{Herbert Pundik}

\section{Den grove svindel med resultatet af Irans præsi- dentvalg førte til omfattende protester med bred folkelig opbakning. Den latente splittelse i Irans ledende eliter er blevet meget tydelig}

Det iranske samfund er så uigennemsigtigt, at hverken udenlandske efterretningstjenester eller landets øverste gejstlige og dermed også politiske overhoveder tilsyneladende havde en anelse om, hvad der bevægede sig under overfladen hos Irans 70 mio. indbyggere.

Denne uigennemsigtighed har blindet Den Øverste Leder og hans allierede for den kendsgerning, at over halvdelen af landets befolkning er født efter revolutionsåret 1979, ikke har kendt shahen og hans frygtede sikkerhedspoliti, Savak, og ikke opfatter Den Øverste Leder som repræsenterende en befrielsesbevægelse, men det modsatte.

Havde Iran Øverste Leder, ayatollah Ali Khamenei, kunnet forudse, hvilke konsekvenser manipulationerne i forbindelse med præsidentvalget ville få, og den dybe splittelse såvel i befolkningen som i den islamiske revolutions ledelse de ville afsløre, ville antireformisterne om- kring Den Øverste Leder næppe have satset så højt på at sikre Mahmoud Ahmadinejad genvalg som præsident.

Det er ikke første gang, der har fundet valgsvindel sted i Iran, men det har aldrig tidligere udløst så voldsomme reaktioner som i juni

Det islamiske samfund er et teokrati, et religiøst terrorvælde, hvor overlevelse forudsætter forstillelse. Ærlig snak kan bringe en i fængsel. Kun de modige tør kritisere systemet, alle andre svarer undvigende på journalistens spørgsmål eller snakker magten efter munden.

Iranerne foregiver religiøsitet på gaden eller på arbejdspladsen, selv om de hjemme bag hjemmets fire vægge bryder koranens love. De råber 'død over Amerika', selv om de dagdrømmer om at få et visum til USA, og de forsvarer over for ukendte fremmede deres lands demokrati, selv om de ved, at Vogternes Råd før det seneste parlaments- 
valg diskvalificerede over 2000 reformvenlige, der havde ansøgt om at blive accepteret som kandidater.

\section{Tilløb til reformer}

De reformvenlige, som bl.a. ønskede at fremme en demokratisk udvikling og større åbenhed i den offentlige debat, havde vundet præsidentvalgene i 1997 og 2001, og den ny præsident, Mohammed Khatami, var indstillet på at bryde Irans internationale isolation og genoptage diplomatiske forbindelser med Washington.

De var blevet afbrudt efter revolutionen, da studenter i november 1979 havde besat den amerikanske ambassade i Teheran og holdt personalet indespærret i 444 dage.

Khatamis otte år blev en skuffelse for de vælgere, der havde bragt ham til magten $\mathrm{i}$ håb om, at han ville modernisere samfundet og indskrænke den konservative, fundamentalistiske fløjs indflydelse. Han var til syvende og sidst en del af systemet og manglede mod til at tage det nødvendige brud med teokraterne omkring Den Øverste Leder.

Ali Khamenei kvalte Khatamis forsøg på at liberalisere lovgivningen. Parlamentet er underlagt et råd, der har myndighed til at nedlægge veto mod love. Og Den Øverste Leder havde som ansvarlig for indenrigsministeriet og retssystemet mulighed for at sabotere præsidentens liberaliseringsbestræbelser.

Kunstnerne fik større frihed un- der Khatami, og sædelighedspolitiet var mindre nidkært i kontrollen af de strenge krav til kvindernes korrekte påklædning. Man så oven i købet mænd og kvinder gå hånd i hånd i Teherans parker. Men med de spage forsøg på liberalisering voksende prostitutionen og antallet af narkomaner. Det samme gjaldt for antallet af skilsmisser og anden 'usædelighed'.

I konservative kredse voksede bekymringen for, at Iran ville svigte revolutionens vej, og dermed bestræbelserne på at sabotere Khatamis reformbestræbelser. Han mistede sin troværdighed blandt vælgerne, og dertil kom, at hans modstandere fik hjælp fra uventet hold, George W. Bush.

\section{Tilløb til åbenhed mod USA}

Khatami havde demonstreret vilje til at reparere forholdet til USA på trods af stor modstand fra konservativ side. Blandt de nationale interesser, USA og Iran har tilfælles, er bl.a. kampen mod talebanerne i Afghanistan. Iran er modstander af sunnimuslimsk radikalisme. Et af Teherans strategiske mål er at bevare ro langs Irans grænser. I Afghanistans tilfælde foretrækker man et moderat muslimsk styre i Kabul frem for de fundamentalistiske talebanere, hvis forhold til shiaislam er betydeligt mere konfliktbetonet end et moderat sunnimuslimsk regimes.

Dertil kommer, at den lette ad- 
gang til narko fra Afghanistan forgifter store dele af Irans ungdom. Ca. 40 pct. er arbejdsløse, og mange henlever et liv i tom lediggang. USA og Iran har således en identisk national interesse i at bekæmpe den opiumproduktion, der er en af talebanernes vigtigste $ø$ konomiske aktiver.

I dagene efter al-Qaeda-angrebet 11. september 2001 på New York og Washington udsendte Khatami en erklæring, hvori han fordømte angrebet. På dette tidspunkt samarbejdede iranske og amerikanske efterretningsorganisationer. De udvekslede informationer om talebanerne, og Iran havde ladet USA forstå, at hvis amerikanske piloter blev tvunget til at nødlande på iransk territorium, ville de have frit lejde.

\section{Amerikansk afvisning}

Hvad var George W. Bushs reaktion på Khatamis signaler? Hans tale til kongressen, hvori han stemplede Iran som en del af 'ondskabens akse' i selskab med Nordkorea og Saddam Husseins Irak. Da USA et par år senere invaderede Irak og væltede Saddam Hussein, var det nærliggende for iranerne at frygte, at de stod for tur.

Bushs fordømmelse satte selvfølgelig en stopper for en tilnærmelse og afslørede Khatami som en politisk dilettant. Karakteristisk for USA's manglende åbenhed over for Khatamis udspil og for politisk forstokkethed er udenrigsminister
Condoleezza Rices svar på et spørgsmål fra den amerikanske journalist Barbara Slavin om hendes reaktion, da hun fik Bushs 'state of the uniontale' til gennemlæsning. "What is funny about it", svarede Rice, "is that it (udtrykket 'ondskabens akse', H.P.) really did not catch my eye".

\section{Ahmadinejad til magten}

Det er som sagt ikke første gang der har fundet valgsvindel sted i Iran. Det skete også ved præsidentvalget for fire år siden, da Ahmadinejad vandt $i$ anden runde over den tidligere præsident Ali Akhbar Hussein Rafsanjani med syv mio. stemmers flertal.

Det affandt vælgerne sig med, for Rafsanjani var ikke populær; i modsætning til Ahmadinejad gad han ikke føre valgkamp ude i de 30 provinser, som Ahmadinejad gennemrejste på kryds og tværs. Den kendsgerning, at den tidligere præsident havde været en af revolutionens fædre som ayatollah Khomeinis nærmeste rådgiver, kunne ikke konkurrere med Ahmadinejads populistiske propaganda, der kørte på hans beskedne oprindelse som søn af en fattig mand.

Blandt de historier, der blev sat i omløb om ham, var den, at han som Teherans borgmester hørte, at kloaksystemet i et af byens kvarterer var brudt sammen. Ifølge historien tog han straks derud og rensede med egne hænder kloakken. 
Den kendsgerning at Rafsanjani var en af Irans rigeste mænd, som ikke havde holdt sig tilbage i de otte år, han var præsident, bidrog heller ikke til hans folkelige popularitet. Set fra Den Øverste Leders og hans ortodokse og konservative allieredes synspunkt havde Ahmadinejad de kvalifikationer, der gjorde ham egnet som redskab. Han havde kæmpet som medlem af Revolutionsgarden under den otte år lange krig mod Irak i 1980'erne og var populær blandt gardisterne.

\section{Revolutionsgarden}

Garden er præsteskabets private hær, og dens chef udpeges af Den $\varnothing v e r s t e$ Leder. Den blev oprettet kort efter revolutionen i 1979 som modvægt til den officielle hær, som præsteskabet ikke turde stole på. Den tjener fortsat som modvægt til den iranske hær, som koncentrerer sig om forsvaret af Irans grænser og blander sig uden om politik, i hvert tilfælde indtil videre. Garden har sine egne fly og flådestyrker og bliver bevæbnet med det mest moderne udstyr. Den er præsteskabets garant, og dens 120.000 mand er stærkt religiøst indoktrineret.

Under de seneste uroligheder udsendte Revolutionsgardens ledelse en advarsel til demonstranterne: "Garden vil med fast hånd og i revolutionens ånd imødegå oprørerne og alle, der bryder loven."

Basij-militsen er en paramilitær bevægelse, der ligesom Revolutionsgarden og militæret sorterer direkte under Den Øverste Leder. Den tæller officielt 1 mio. medlemmer og blev bragt $i$ anvendelse under junidemonstrationerne som gardens 'tæskehold'. Klædt i civil, ofte på motorcykler og bevæbnet med køller, terroriserede de demonstranterne.

Deres vogne er ofte parkeret ved nedgange til metroen i Teheran. De indfanger kvinder, der er upassende klædt, og bringer dem til de ventede biler, hvor der bliver holdt standret. Kvinderne idømmes bøder eller husarrest. Der er rapporter om, at især helt unge kvinder er blevet tvunget til at klæde sig af. Deres protester blev afvist med den bemærkning, at de alligevel var skøger.

Ahmadinejad er gardens mand. Han er besjælet af shiamuslimsk mysticisme, hvori indgår tro på, at dommedag nærmer sig som varsel om den shiamuslimske frelser, den 12. imams, Mahdiens, genkomst. $\mathrm{Og}$ så er han en brændende patriot, der er overbevist om, at USA's invasion af Irak og Saddam Husseins fald er indledningen til et angreb på Iran med henblik på at gennemtvinge et regimeskifte.

Ahmadinejad var således ideelt egnet til at bremse de reformvenlige kræfter, som den øverste leder Khamenei og hans allierede mente udgjorde en fare for den revolutionære vej og ikke mindst for Khameneis position som Khomeinis arvtager. 


\section{Konservativ offensiv}

Ahmadinejad indledte straks efter sin indsættelse som præsident i 2005 en konservativ offensiv mod reformisterne. Bushs åbne konflikt med den muslimske verden så de konservative som en kamufleret kamp mod islam. De militære tilbageslag i Irak og Afghanistan underminerede de amerikanske sikkerhedsgarantiers troværdighed i forhold til magthaverne i de såkaldt moderate arabiske lande. Udviklingen opmuntrede de konservative kredse i den iranske ledelse, der opfattede Khomeinis pålæg om at bygge et retfærdigt samfund på islams værdier som et revolutionært budskab ikke blot med adresse til det iranske samfund, men rettet med hele den arabiske verden.

Ahmadinejad begyndte sin præsidentperiode med at foretage en række udrensninger dikteret af ideologiske hensyn. Han afskedigede 'upålidelige elementer' på universiteterne. Udskiftede erfarne diplomater med rettroende, uanset deres kvalifikationer. Den iranske ambassadør i Danmark fx behersker engelsk så dårligt, at han altid taler gennem en tolk.

Omkring to tredjedele af de 30 provinsguvernører og mange af topcheferne i regeringsejede firmaer blev udskiftet med officerer fra Revolutionsgarden, der ikke blot militært, men også økonomisk er en stat i staten. Den kontrollerer store monopoler, der sammen med de store islamiske fonde er revolutionens økonomiske rygrad, uden for statens kontrol.

En økonom fra Verdensbanken fortæller, at det er umuligt at vurdere effekten af Sikkerhedsrådets økonomiske sanktionsresolutioner, fordi den iranske nationalbanks oplysninger om landets økonomi er lige så uigennemskuelige som samfundet i øvrigt.

De omfatter fx ikke oplysninger om de store islamiske fondes formuer og transaktioner.

Mange af de oliepenge, som Iran har tjent, og som udenlandske økonomer ikke kan gøre rede for, menes at være skjult i de islamiske fonde til brug som stødpuder, såfremt sanktionerne vil blive yderligere strammet.

Ahmadinejad har brystet sig af, at han ikke har forstand på økonomi. Han henter sin inspiration fra islam. "Hvert projekt, hver anvendt metode og hver administrativ procedure", har han sagt, "udgår fra islams hjerte".

At islam ikke er den bedste vejleder i økonomiske spørgsmål, viser nogle økonomiske nøgletal. Den årlige inflation i Iran er officielt 15 pct., men skønnes af uafhængige iagttagere snarere at være på 25 pct. Ungdomsarbejdsløsheden er på 40 pct. og stigende, fordi økonomien ikke kan producere de 900.000 nye job pr. år, der er en forudsætning for, at arbejdsløsheden kan holdes konstant. 


\section{Modernisternes kritik}

Ahmadinejad blev i sin første præsidentperiode de ortodokse, fundamentalistiske gejstliges håndgangne mand, og fra 2005 voksede splittelsen mellem modernister og traditionalister blandt de ledende veteraner fra Khomeini-perioden.

Blandt Khameneis kritikere er en del højtstående gejstlige, som er modstandere af den sammenblanding af religion og stat, som Khamenei repræsenterer. De er enige med den islamiske revolutions mål om at opbygge samfundet på islams principper, og de mener, at der i 1979 var tale om en nødsituation, hvor det var korrekt, at præsteskabet greb ind. Men efter 30 år mener de, at præsterne skal abdicere til fordel for politikerne, trække sig tilbage fra det politiske liv og koncentrere sig om det, der er deres hellige pligt ifølge islam: at optræde som lovens og dermed retfærdighedens vogtere.

En anden gruppe af Khameneis gejstlige modstandere kritiserer ham for at have tiltaget sig rollen som ikke blot shiaislams, men hele islams overhoved, selvom det er velkendt, at han med hensyn til lærdom er andre ayatollaher langs underlegen. Det gælder dels storayatollah Hossein-Ali Montazeri, der lever i eksil i den hellige by Qom, som er Irans religiøse centrum, dels den irakiske storayatollah Ali Sistani, der også har mange tilhængere i Iran.

Khamenei beskyldes for at føre sige frem, som om han havde en særlig tilknytning til den shiamuslimske messiasskikkelse, det 12. imam, hvilket i ortodokse muslimers øjne grænser til blasfemi. Han fremsætter udtalelser, der bærer præg af en særlig indsigt, som er forbeholdt den forsvundne Mahdi. Et genskær af dette forklaringens lys har han ladet skinne på Ahmadinejad, hvis tilhængere fortæller, at de så en ring af lys svæve over præsidentens hoved, da han for et års tid siden holdt et foredrag på Columbia University i New York for en dybt fjendtlig forsamling.

Ali Khamenei er således under angreb ikke blot fra modernister, bl.a. repræsenteret ved Ali Akhbar Hashemi Rafsanjani, men også fra andre indflydelsesrige grupper i præsteskabet. Hans rolle i konflikten omkring Ahmadinejads genvalg har kompromitteret ham i mange rettroendes øjne. Som landets øverste leder var det hans opgave at sikre retfærdighed; i stedet blandede han sig direkte i valgkampen mod reformtilhængeren Mir-Hussein Mousavi.

Han sendte bl.a. en besked til medlemmerne af basij-militsen, hvori han opfordrede dem til at stemme på Ahmadinejad. Et budskab, der i betragtning af at basij-militsen er direkte underlagt Den $\emptyset$ verste Leder, kun kunne opfattes som en ordre. 
Kampen om præsidentposten mellem den reformvenlige Mousavi og den hellige kriger Ahmadinejad var et afgørende øjeblik i kulturkampen mellem modernister og traditionalister. Begge kandidater tilhører revolutionens elite, begge er af den opfattelse, at Iran skal være et samfund bygget på islamiske værdier. Uenigheden handler om vejen mod målet i en globaliseret verden karakteriseret af voksende internationalt samarbejde og i et samfund, hvor ungdommen ikke længere lader sig spise af med revolutionære og religiøse slogans i stedet for beskæftigelse og lysere fremtidsudsigter.

\section{Atomprojektet}

Irans atomprojekt, der hypnotiserer omverdenen, indgik overhovedet ikke i valgkampen. Der er national enighed bag projektet, som de fleste iranere opfatter som defensivt og en sikkerhedsgaranti mod angreb på landets suverænitet. Forskellen mellem traditionalisternes og modernisternes indstilling til Iran som en kernevåbenmagt er et spørgsmål om nuancer.

Reformisterne er indstillet på en kompromis med USA bygget på den japanske model. Japan behersker den nødvendige teknologi og er i stand til at samle en atombombe i løbet af et halvt til et helt år. Traditionalisterne er modstandere af den japanske model. De foretrækker den nordkoreanske, dvs. ja til for- handlinger med USA, men først efter at Iran har foretaget den første prøvesprængning.

Det nordkoreanske eksempel bekræfter, at USA's forhandlere udviser større respekt og smidighed under forhandlingerne, efter at Nordkorea har tiltvunget sig adgang til atomklubben. Og ikke mindst respekt spiller en afgørende rolle i Irans forhold til omverdenen. Respekt viser, at man er ligestillet, et af Irans strategiske hovedmål i konflikten med USA.

\section{Kulturkampen}

Valgkampens udfald var således af afgørende betydning i den underliggende kulturkamp. Den reformvenlige Mousavi udgjorde en trussel mod det bestående konservative system med Ali Khamenei som topfigur. Ahmadinejad skulle for enhver pris genvælges, så han kunne fortsætte sin hellige gerning og fordrive de tiloversblevne rester af Khatamis otte år som præsident. At Khamenei opfattede ham som en farlig modstander, viser den ildhu, hvormed politiet har arresteret personer i kredsen omkring ham, bl.a. en af hans tidligere vicepræsidenter, hans tidligere viceindenrigsminister og en af hans førende politiske strateger.

Den Øverste Leder og hans allierede tog fejl, da de manipulerede valgresultatet så groft, at indenrigsministeriet offentliggjorde valgresultatet, inden man havde kunnet nå at 
bringe alle stemmebokse fra et område, der er tre gange så stort som Frankrig, til Teheran, hvor de skulle tælles centralt for at sikre kontrol med resultatet.

Ahmadinejad fik dobbelt så mange stemmer som Mousavi. Iranerne er som sagt ikke fremmede for valgsvindel, men dette resultat forekom Mousavis tilhængere grotesk, en fornærmelse, et tegn på systemets totale mangel på respekt for borgerne.

Situationen var anderledes end for fire år siden. I modsætning til den problematiske, arrogante Rafsanjani, er Mousavi en højt respekteret kulturpersonlighed. Han var også en af revolutionsfaderens nærmeste. Han var statsminister i de svære krigsår i 1980'erne, og han var i øvrigt den, der rejste spørgsmålet om en iransk atombombe på et tidspunkt, hvor irakiske tropper truede den iranske by Shiraz, der ligger ca. $800 \mathrm{~km}$ syd for Teheran.

Siden krigens afslutning i 1989 havde Mousavi ikke været politisk aktiv. Ydmygelsen krænkede hans vælgere, i hvis opfattelse Mousavi repræsenterede den islamiske revolutions grundværdier i modsætning til Den Øverste Leder, Khamenei.

Der var voksende uro blandt ungdommen på grund af den høje arbejdsløshed og de højere læreanstalters adgangsbegrænsning. Og endelig voksende utilfredsheden blandt kvinderne med det officielle Irans religiøst motivere kvindeundertrykkelse i en situation, hvor to tredjede- le af alle studerende er kvinder.

Det var ikke islams krav om tildækning af kvindens hår uden for hjemmet, der var udslagsgivende. Det var fornemmelsen af at blive behandlet som de andenklasses borgere, de måtte affinde sig med at være i et islamisk samfund. Der var tale om et udbrud af utilfredshed, ikke om en revolution. Tv-billederne viste drabelige slagsmål mellem basijmilitsen, revolutionsgardisterne og demonstranterne. Der blev affyret skud, men der var ikke tale om et blodbad. Der foreligger ikke tal fra provinsbyerne, men end ikke de vildeste twitter-rapporter taler om flere end 30 dræbte.

Mousavi mistede meget hurtigt kampgejsten. Den ene dag erklærede han, at han var villig til at lide martyrdøden, et par dage senere opfordrede han demonstranterne til at undgå vold. Transparenterne $o g$ slagordene viste, at der ikke var tale om et ideologisk oprør mod den islamiske republiks undertrykkelsesregime. Ingen råbte 'brød eller død' eller 'arbejde og frihed'. Mousavi opfordrede folk til at råbe 'Allahu akhbar' - gud er stor - fra Teherans flade tage. Det var mest af alt et familieslagsmål. Ingen lederskikkelse dukkede frem af anonymiteten. De centrale skikkelser var alle medlemmer af den islamiske revolutions elite. Rafsanjani og Mousavi, Khatami Khamenei og Ahmadinejad. Ingen vovede at bryde med teokratiet. Rafsanjani, der er Den Øverste Leders 
mest indflydelsesrige modstander kunne have gjort en forskel. Bl.a. er han formand for Eksperternes Råd, der formelt udnævner Den Øverste Leder og har til opgave at overvåge ham. Men han vovede ikke at bryde med arven fra revolutionens fader, Ruhollah Khomeini.

Som i alle autokratiske systemer er det Den Øverste Leders vigtigste opgave at overleve, bl.a. fordi den absolutte magts alternativ ikke er opposition, men absolut afmagt og politisk fortabelse, i værste fald også fysisk.

\section{Hvor går Iran hen?}

Demonstrationernes udfald viser, at den islamiske revolution i Iran har permanent karakter. Den konservative fløj kan kun væltes indefra. Det forudsætter enten en alliance mellem reformisterne og en liberal fløj blandt traditionalisterne, som vil kunne give oppositionen legitimitet i revolutionens og islams navn, eller militærets indgriben.

Indtil videre kan udviklingen $\mathrm{i}$ Iran gå i to retninger. Enten kan Den Øverste Leder, støttet af Ahmadinejad og Revolutionsgarden, iværksætte et terrorregime for at kvæle ethvert tilløb til opposition, lukke omverdenen ude og hengive sig til den martyrrolle, der er en central del af shiamuslimsk fortolkning af islam, og som bl.a. har sin oprindelse i overbevisningen om, at shiamusli- merne, der nedstammer i lige linje fra profetens efterkommere, blev snydt for deres retmæssige arvelod af sunnierne.

Eller også kan Den Øverste Leder vælge at tage bestik af den sociale uro og utilfredsheden med forholdene i samfundet efter 30 års islamisk styre, skille sig af med Ahmadinejad og redde sit skind.

Efter junidemonstrationerne er der behov for rehabilitering af den islamiske revolutions institutioner, af Den Øverste Leders, Ali Khameneis, position som repræsentanten for islamisk retfærdighed og af landets økonomi, så den kan skabe en balance mellem de unges forventninger til staten og statens krav om tilpasning til islams krav om underkastelse.

Måske er Ahmadinejad dage talte. Det afhænger ikke mindst af, om omverdenen kan afholde sig fra indblanding.

Systemets bedste allierede i kampen for at bevare magten er den iranske befolknings dybe uvilje mod udenlandsk indblanding. Efter i de sidste hundrede år at have været kastebold mellem russiske, engelske og amerikanske interesser, overgår behovet for nationalt sammenhold og forsvar mod fjender, der i et vist omfang er produkter af iransk fantasi, næsten alle andre hensyn.

Herbert Pundik er seniorkorrespondent for Politiken. 